\title{
PRICE DISCOUNTS AS A GOODS PROMOTION FACTOR IN LATVIAN RETAIL TRADE
}

Iveta Linina ${ }^{1}$,Dr.oec.; Ieva Bruksle ${ }^{2}$, Mg.oec. and Rosita Zvirgzdina ${ }^{3}$, Dr. oec.

Abstract. Retail trade plays a significant role in the economy of any state. In business, a relationship between the company and the consumer is formed and both sides have their own certain benefits they wish to acquire from this relationship. For the company the main goals are to increase the turnover and gain profit, however, for the consumer aims may vary. In order to attain their goals, being the increased turnover and incoming profit, the companies can use different tools to stimulate the consumer's choice of the product. Sales promotion is exactly what ensures the opportunity for the retailer to attract customers and motivates that particular choice of the purchase, what furthermore ensures competitive advantages over other competitors. The globalization of the market also affects the retailing companies more and more and, therefore, pushes them to find new solutions to ensure their competitiveness and development. To identify the factors that guarantee the competitiveness, the authors have established the research of price discounts as a tool for sales promotion and its effect upon the activity of the retail companies as their research focus. Furthermore, the authors will research the form of sales promotion- theoretical basis of usage of price discounts as a part of marketing communication. Moreover, they will also analyse tendencies of development of retail trade in Latvia, as well as, clarify the consumers' attitudes towards the price discounts and the impact of them on making purchases at retail outlets in Latvia by conducting a consumer survey. This research will offer an understanding about the impact of commodity price rebates on consumer behaviour and point to the specificities of this process in retail to the retail companies. From the scientific point of view in this work the authors have collected the analysed theoretical aspects and have defined a united approach for building up the discount policy for retail businesses. As a result of the research, the authors conclude that by examining consumer attitudes towards the commodity price discounts and their use, companies can manage this process and perhaps it may become one of their tools for maintaining competitiveness.

Key words: customer, retail trade, product promotion, discounts.

JEL code: F1; F6; M1; M3.

\section{Introduction}

Market globalization affects retail companies more and more and causes them to search for new solutions that ensure competitiveness and supports development. In circumstances of more intense competition, it continuously becomes harder to ensure competitiveness. One of the ways to become more competitive is to focus on customer satisfaction and loyalty. Customer satisfaction and loyalty building is based upon receiving the necessary information, attitude and the requested commodity at the right place, amount and a price that is suiTable the customer. The product price discount as a way of sales promotion can possibly increase the turnover yet decrease the profit. In a retail company it is significant to understand consumer attitude towards the discounts and to develop a targeted approach supported by this attitude. This approach can be developed in many ways, however, it has one certain focus- to support a competitive and sustainable development of a trading company. Latvian retail companies are very intensively using commodity price discounts as an incentive to make a purchase, however, this process is chaotic and not always reaches the goal. This research is looking at the habits of application of discounts in Latvian retail companies as well as at the consumer behaviour when shopping. By understanding decisions customers make when shopping, a retail company can create a more targeted commodity price discount process with more effort, as well as, increase the competitiveness. To identify factors that are ensuring the competitiveness the authors have focused their research on studying the shopping habits of Latvian residents, that furthermore

\footnotetext{
${ }^{1}$ Tel.: +371 26306922. E-mail address: iveta.linina@turiba.Iv

2 Tel.:+371 29404321. E-mail address: ievab@turiba.Iv

${ }^{3}$ Tel.: +371 26408253. E-mail address: Rosita@turiba.Iv
} 
will allow the retail companies to develop a commodity price discount policy and, therefore, apply that as a factor influencing the choice of purchase and improve their performance and competitiveness.

To attain the goal following tasks were put forward:

- To analyse theoretical aspects of the use of the discount as a factor affecting the purchase.

- To define the Latvian retail trade field and its tendencies of development.

- To determine the habits of consumer shopping and attitude towards commodity price discounts and their effect on the customers' choice.

To determine customer shopping habits and commodity price discount's influence on the purchase, Latvian residents were surveyed, and limitations were set such as: the problem is studied mostly from the methodological point of view and the nationality, place of residence or income level of the respondents of the survey were not considered. The period of the research: from 1st July 2018 to 1 st January 2019.

Following methods of research are used: the logically- constructive method to compare the theoretical material with the empirical results; the graphical method for visualization and analysis of the visual information and customer survey. The methodological basis of the study is foreign (Blattberg\& Neslin, Kotler\&Keller, Cummins, Chernev, Blythe, Goodluck, Wineaster, Stiving, RuskinBrown etc.) works and publications that provide insight into the latest information on consumer shopping habits and attitudes towards commodity prices at a discount.

\section{Research results and discussion}

\section{Sales promotion and discounts}

At the beginning we want to provide insight into the essence of sales promotion and to emphasize the opinions of different authors about the use of such promotion tool as price discount.

Blattberg \& Neslin considers that sales promotion, a key ingredient in marketing campaigns, consist of a collection of incetive tools, mostly short term, designed to stimulate quicker or grater purchase of certain products or services (Blattberg, Neslin, 1990). However, Kotler\&Keller notes that if advertising offers a reason to buy, then sales promotion offers an incentive to buy. Promotion induces consumers to try new products and lead to more varied retail formats, such as everyday low pricing and promotional pricing. For retailers, promotions may increase sales of complementary categories as well as induce store switching. They promote greater consumer awareness of prices. Service marketers also use sales promotions to attract new customers and establish loyalty (Kotler, Keller, 2009). Cummins considers that promotions are primarily tactical in nature but can be a part of a long - term strategy. They must be understood in the context of the functional, economic and psychological benefits with which firms seek to meet customer needs. Promotions are a tool to influence the behaviour and alter every part of the marketing mix to do so. The core of sales promotion is the attempt to influence behaviour here and now. It is the range of price and value techniques designed within a strategic framework to achieve specific goals by changing any part of the marketing mix, normally for a defined period (Cummins, 2010).

It is indicated that promotions work in three ways: economic value, the value resulting from the discounts; information content: the message implied by discount; and affective appeal, feeling aroused by the discount (Davis, 2017). Goodluck\& Wineaster emphasizes that sales promotion could be a vital tool when introducting a product internationally (Goodluck, Wineaster, 2016). 
Kotler \& Keller notes that sales promotion includes different tools for consumer promotion; the ones directly price-oriented are: coupons and prices off (Kotler, Keller, 2009). Chernev characterizing management of incentives mentions that incentives offer solutions, typically short - term. Incentives can be either monetary - such as volume discounts, price reductions, coupons or rebates or nonmonetary. All incentives can be divided into three categories: incentives given to customers (customers monetary incentives: coupons, rebates, price reductions, volume discounts), incentives given to the partners and incentives given to the employees (Chernev, 2012). Blythe describing price promotion, points to two discount categories - immediate and delayed discounts, and five immediate discount forms: seasonal discounts, multibuys, banded packs, reduced shelf price and extra- fill packs (Blythe, 2006).

Stirving thinks that segmenting prices through customer behaviour is fascinating. Their behaviours indicate their willingness to pay. Coupons are a common way to implement segmentation pricing, however, rebates are similar to coupons, only better. Sales events, end- aisle displays, purchase ahead and loyalty clubs are also mentioned. (Stiving, 2011)

Norton analysing sales promotion techniques points to the price pack advantages: moves merchandise and keeps up visibility and disadvantages: not selective and may cheapen brand image (Norton, 2005). However, it is important to use these incentives wisely. Cummins notes that deciding on the optimal mix of incentives (or sales promotion instruments), price promotion is playing with fire. All the surveys show that consumers prefer price promotion to any other form of promotion. They also show that it devalues brand and leads to an expectation of even higher price promotion. Promoters are most likely to use price promotion effectively if they think in terms of segment pricing, look for concrete benefits from each discount they put and use price promotion intermittently. Price promotion continues inevitably by trade pressures and competition (Cummins, 2010). It can be facilitated by using a systematic approach (Chernev, 2012).

It also points to the risks arising by the use of discounts. Davis considers that the main risk of using price discounts is that competitors can easily retaliate in kind, leading to a price war that is damaging to both parties and ultimately weakens the industry, leaving it open to an attack from less immediate competitors (Blythe, 2006). Discounts may make sale today, but what are the long-run costs? Customers may have been bluffing, may be willing to buy at a compromise discounts, or may return after realizing a product's relative value over the new entrant. Additionally, profits will drop if others byer's find out about and start demanding a similar discount (Mohammed, 2010). Kotler \& Keller notes that discount pricing has become the modus operandi of a surprising number of companies offering both products and services. Some product categories tend to self-destruct by always being on sale. Sales persons are quick to give discounts in order to close a sale, discounting becomes the norm, but the discounts undermine the value perceptions of the offering, but at the same time discounting can be a useful tool (Kotler, Keller, 2009). Promotions should generate additional sales volume, but the greater challenge is doing so profitably (Davis, 2017). Therefore, it is important to understand the purpose of the discounts, to develop a system or specific program and to evaluate the results.

Ruskin- Brown has defined rules for discounting that if adopted will help to reduce the otherwise erosion of profits: don't publish discounts; negotiate discounts individually; vary the terms a lot; put a limit on every deal; renegotiate every lapsed deal; never let discounts become rooted in your price list/structure; if in any doubt- set prices high and give large discounts; keep the situation flexible for yourself as long as possible (Ruskin- Brown, 2008). 
We want to point out that price promotion, discounting and the impact of the discounts has been studied by various authors (Carlson\&Kukar-Kinney, 2018, Liu, Chiu, 2015, Graciola, De Toni, 2018), the use and impact of discounts in different areas has been analyzed in other studies (Jadidi et.al. , 2017, Balut et. al., 2018, Xu et. Al, 2019, Miettinen, Stenbacka, 2018), and consumer reaction (Mao, 2016, Shirai, 2017).

\section{Retail sales and discounts in Latvia}

The subject of the research is the retail sector. Retail is an intermediary in the product distribution channel (PIK). PIK is a set of interconnected companies that participate and perform all of the functions in the process of transferring, distributing, promoting and selling products and related values from manufacturer to consumer (Kotler, et al., 2011). The development of retail companies in recent years has shown that retail is generally a profiTable business in Latvia, as evidenced by the dynamic increase of turnover every year since the end of the global economic crisis.

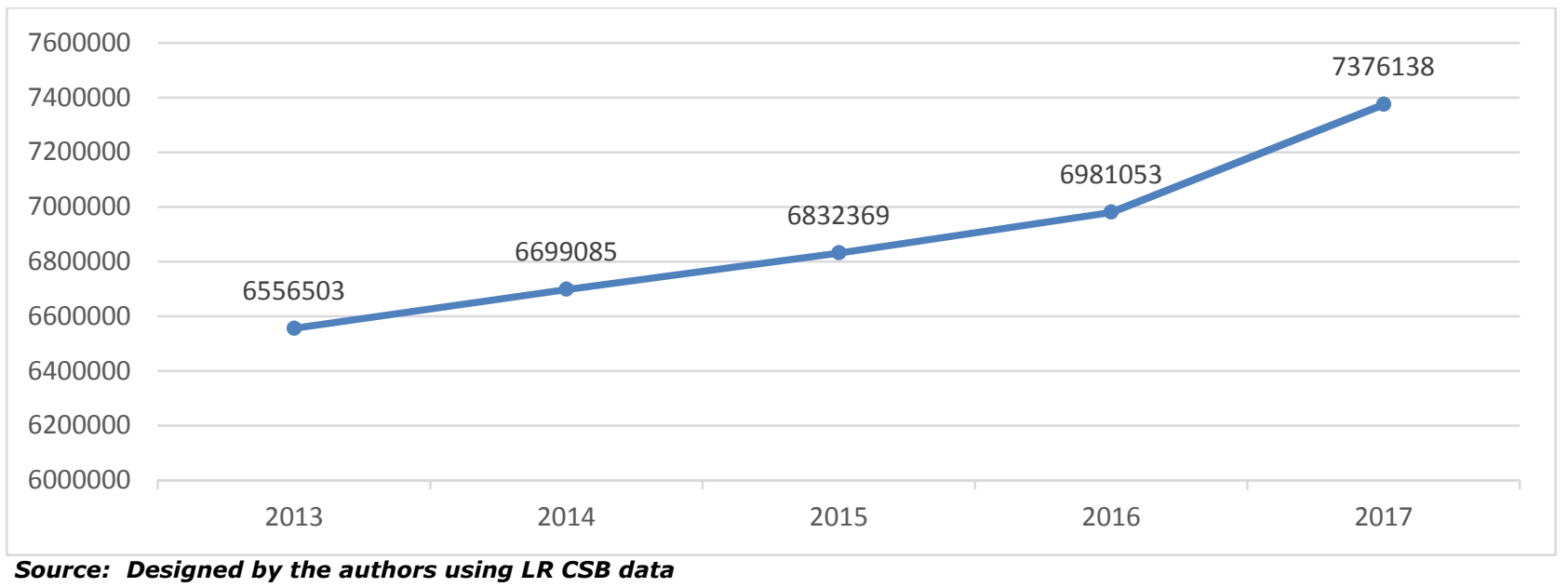

Source: Designed by the authors using LR CSB data

Fig. 1. Retail sales in Latvia (thousand euro)

Compared to 2013, the total retail trade turnover of Latvian retail companies has increased by $13 \%$ in 2017 (Figure 1). At the same time, it has to be taken into account that there are different market players in the trading sector and, like in other countries, there is a tendency in Latvia that it is more and more difficult for the small retailers to stay in the market when the strong retail networks develop and strengthen. In order for retail businesses to be competitive and to increase turnover, demand must be stimulated. Demand can be stimulated by various marketing activities, including one of the sales incentives - commodity price discounts.

In order to successfully apply this method of demand stimulation - commodity price rebates, it is essential to study consumer attitudes towards them.

A population survey was conveyed to study consumer attitudes and buying behaviour. Taking into account the purpose of the survey, the authors of the work chose a standardized open questionnaire. This means that all respondents were asked the same questions with the same order, which ensures an objective comparison of the answers. The questions were selected with one answer according to Likert's 5-point scale and other answers in the system. The questionnaire was created on the Google Forms website and with the non-probabilistic Snowball method (Kristapsone, et.al, 2011). Through the personal contacts of the authors, it was sent to the respondents via e-mail who further shared the link. For the purpose of the study, 1004 respondents filled in questionnaires that were accepted as valid, which at the $95 \%$ confidence level and $5 \%$ error limit sample is sufficient to ensure the representativeness of the study (Arhipova, Balina, 2006) 
Within the framework of the research, the criteria affecting the selection of the consumer retail company were ranked according to their importance and their real evaluation. These two indicators were compared, and it can be concluded that the price level (3.92) is the most important criterion for choosing a retail company, but the convenience of shopping is the least important. However, when assessing the real situation in retail companies, the price level (3.33) is the least appreciated factor pointing at the negative attitude of consumers towards the pricing policy in retail (Figure 2).

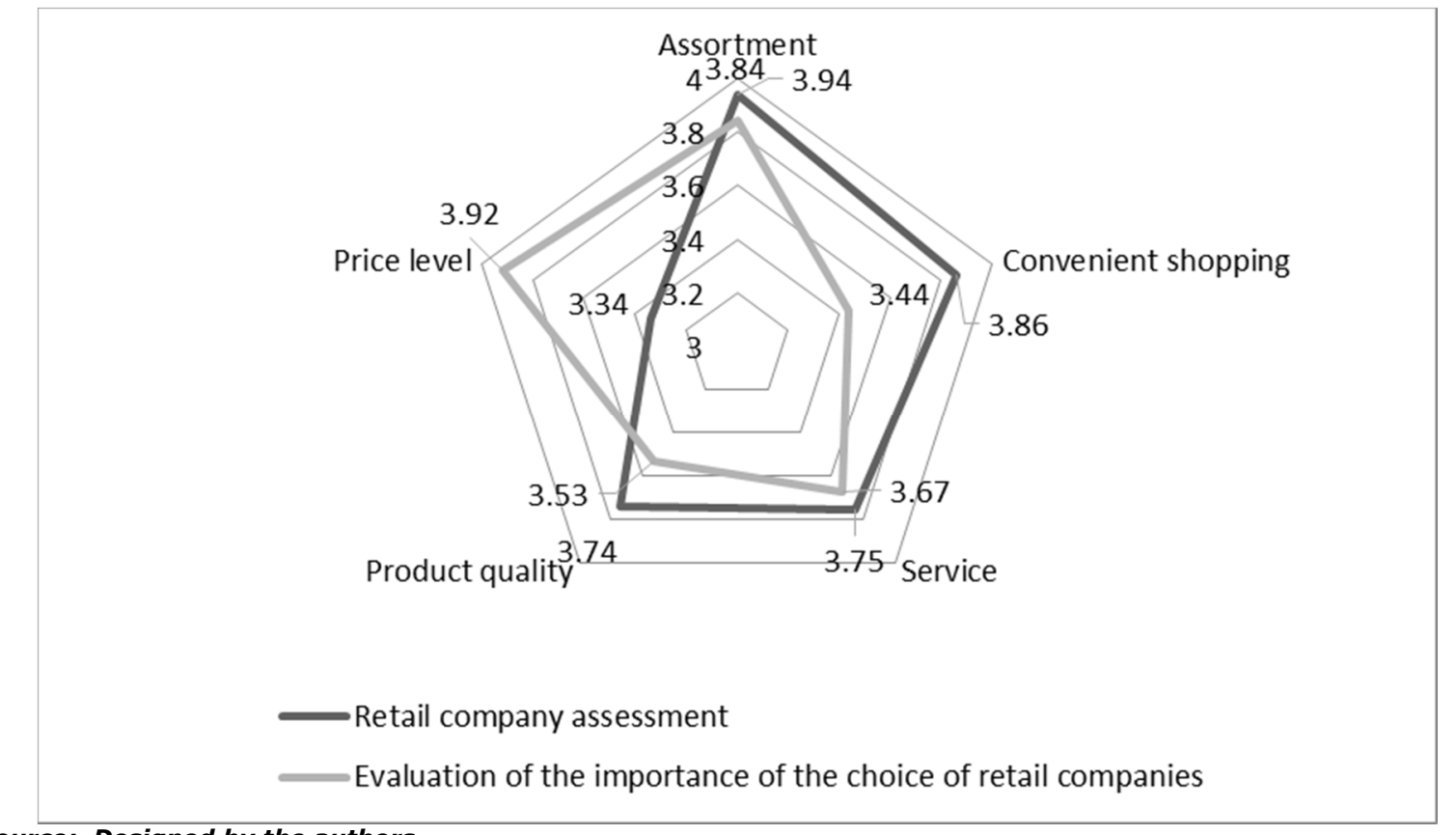

Source: Designed by the authors

Fig. 2. Comparison of the importance of the choice of a retail company with the actual situation assessment

The main objective of the study is to find out consumer perception on pricing in retail businesses. As it can be seen in Table 1, ratings are lower than the pricing-rating score of 3.92 (Figure 2).

Table 1

Indicators of consumer reviews about the pricing in Supermarkets

\begin{tabular}{|c|c|c|c|c|c|c|c|c|c|c|}
\hline Pricing & $\begin{array}{c}\text { Arithmetic } \\
\text { mean }\end{array}$ & $\begin{array}{c}\text { Arithmetic } \\
\text { mean } \\
\text { standart } \\
\text { error } \\
\end{array}$ & Median & Mode & $\begin{array}{l}\text { Standard } \\
\text { deviation }\end{array}$ & Dispersion & $\begin{array}{l}\text { Range of } \\
\text { variation }\end{array}$ & Min & Max & Sum \\
\hline $\begin{array}{l}\text { For most goods, } \\
\text { the prices are } \\
\text { appropriate to } \\
\text { their value } \\
\end{array}$ & 3.31 & 0.04 & 3.00 & 3.00 & 0.85 & 0.72 & 0.06 & 1 & 5 & 1462 \\
\hline $\begin{array}{l}\text { Most prices of } \\
\text { the goods are } \\
\text { appropriate to } \\
\text { their quality }\end{array}$ & 3.21 & 0.04 & 3.00 & 3.00 & 0.89 & 0.80 & 0.06 & 1 & 5 & 1418 \\
\hline $\begin{array}{l}\text { Frequently } \\
\text { purchased goods } \\
\text { have regular } \\
\text { discounts }\end{array}$ & 3.45 & 0.04 & 3.00 & 3.00 & 0.89 & 0.79 & 0.06 & 1 & 5 & 1525 \\
\hline $\begin{array}{l}\text { Price discounts } \\
\text { are essential }\end{array}$ & 3.51 & 0.05 & 3.00 & 3.00 & 1.02 & 1.03 & 0.07 & 1 & 5 & 1553 \\
\hline $\begin{array}{l}\text { Price discounts } \\
\text { are fair (old and } \\
\text { new prices are } \\
\text { indicated) }\end{array}$ & 3.35 & 0.05 & 3.00 & 3.00 & 1.05 & 1.1 & 0.07 & 1 & 5 & 1481 \\
\hline
\end{tabular}

Source: Designed by the authors

There are also doubts that the price discounts are fair $(\bar{X}=3,35 ;$ Me $=3,00 ;$ Mo $=4,00)$. A slightly higher rating was given to discounts on regular purchases $(\bar{X}=3,45 ; \mathrm{Me}=3,00 ; \mathrm{Mo}=3,00)$. Respondents rated two indicators - commodity price for its value and quality the lowest $(\bar{X}=3,21$; 
$M e=3,00 ;$ Mo $=4,00)$. Obviously, the pricing process associated with working with suppliers and other partners needs to be improved. At the same time, the supply-demand ratio for each product and the demand elasticity should be taken into account.

A question was asked about the proportion of discount goods in the shopping cart, where one can clearly conclude that consumers choose goods with discounts (see Figure 3 ).

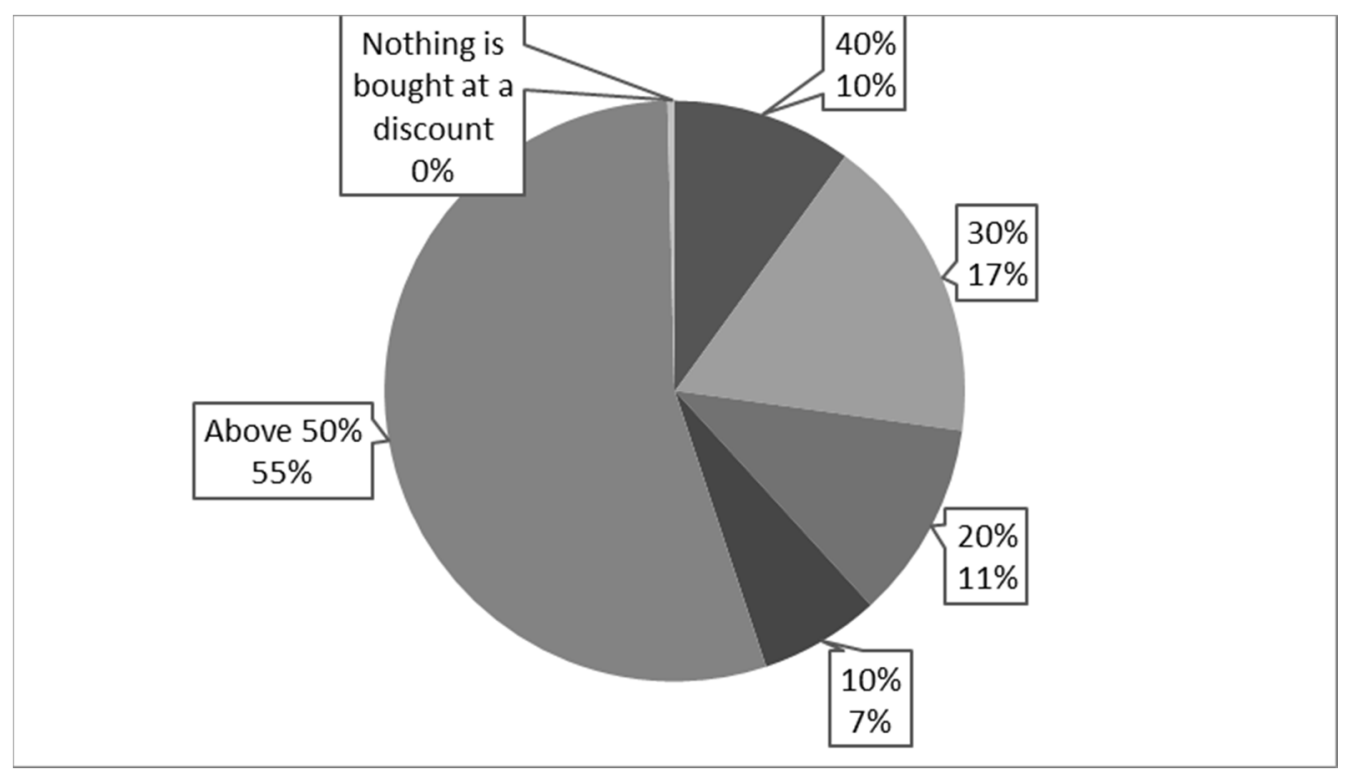

Source: Designed by the authors using Maxima KOMPASS data

Fig. 3. Share of discounts in the shopping cart

More than half of respondents ( $55 \%$ ) replied that more than half of all purchases (over $50 \%$ ) are discounted and there are No consumers with No discounted items in their shopping cart. In addition, buyers perceive discounts very seriously, and refuse to buy finding that there are No discounts (50.3\%) and even complain about buyers misleading (Figure 4).

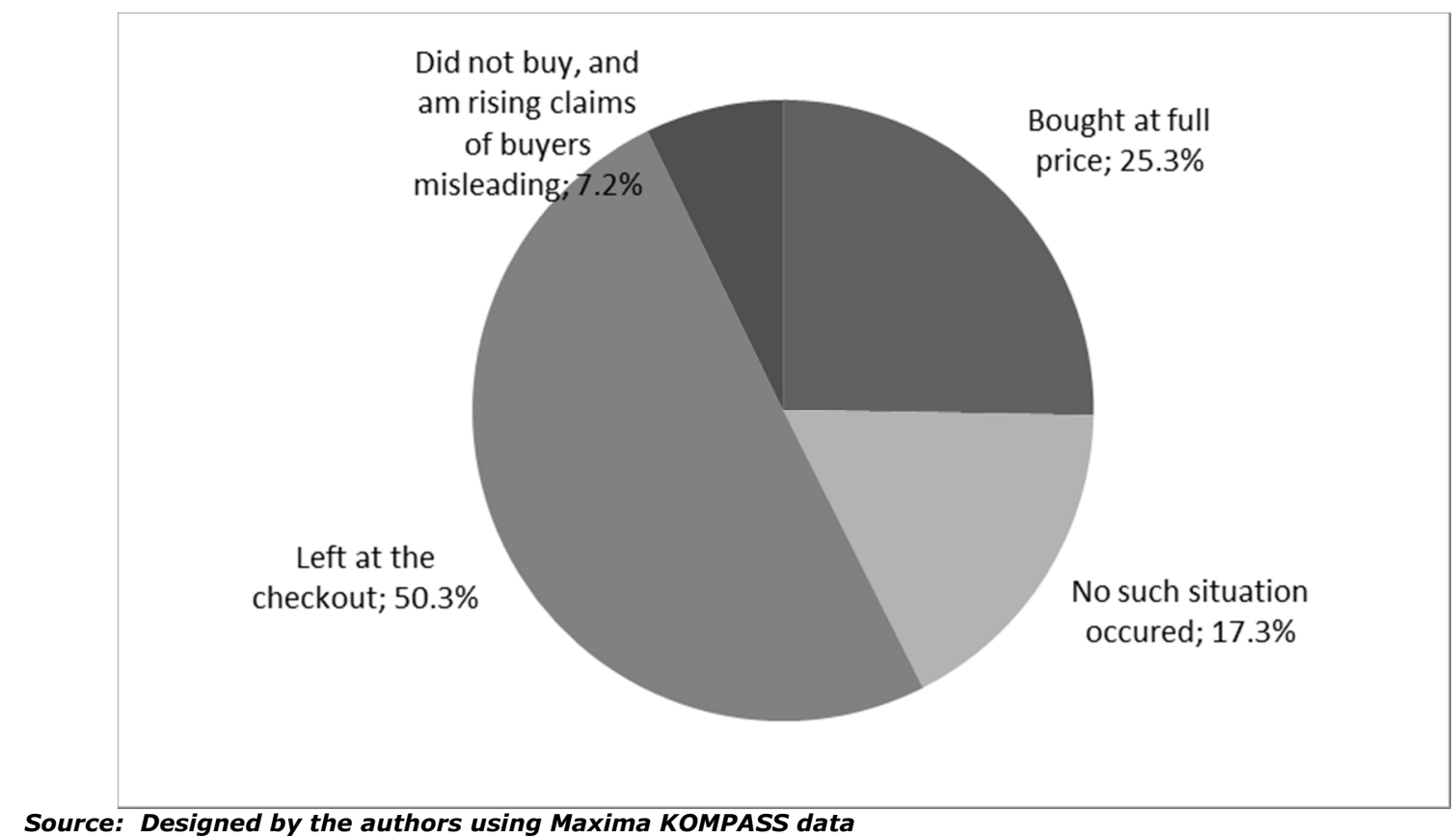

Fig. 4. Residents' actions, if it turns out that the product has No discount

A very important factor for retail businesses is changing the place of purchase of the consumer by choosing the most advantageous offer (Figure 5). 


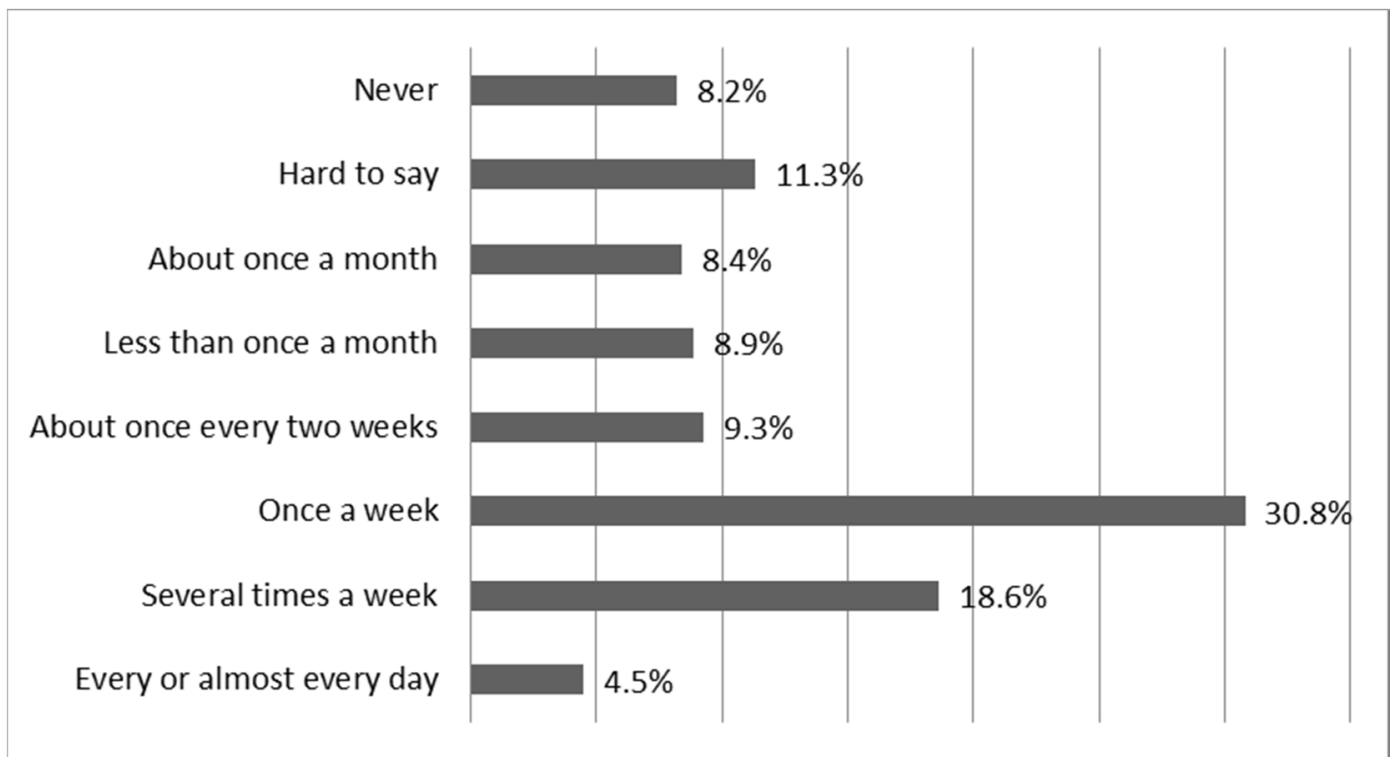

Source: Designed by the authors using Maxima KOMPASS data

Fig. 5. Changing shopping location by choosing the best deal

The majority $(80.5 \%)$ of respondents are willing to change their shopping place more often or less to get the most advantageous offer and only $8.2 \%$ doesn't do that, but $11.3 \%$ find it difficult to answer this question. A third (30.8\%) of respondents even go once a week to look for a better offer. It is this issue that makes retail companies in Latvia seriously consider pricing and be more dedicated and responsible when discounting.

\section{Conclusions, proposals, recommendations}

1) Various authors have studied the use of price rebates and their impact on customer behaviour, both in terms of benefits and risks

2) In order to mitigate the risks of using discounts, it is essential to set the purpose of applying discounts and evaluate the results.

3) Retailing in Latvia is a very fast-growing economic sphere, but it is dominated by the big trading networks, which squeezes out the small businesses from the market.

4) One of the main criteria for consumer when choosing the place to shop is the company's price level, but the assessment of the real situation for the companies' price offer is low.

5) Retailers need to improve their pricing processes, as consumers have rated the price quality ratio of commodity prices very low, what furthermore requests more work with the suppliers and other partners. At the same time, the supply-demand ratio for each product and demand elasticity should be taken into account as well.

6) The fairness of the discount on the price of the goods was also assessed very low. In the perception of consumers, discounts are not fair, which an essential factor is in corporate's social responsibility and is at the heart of the company's image.

7) All the buyers surveyed have one or even more than half of the goods with a discount in their shopping cart, which indicates the importance of this incentive on the purchase.

8) The policy of pricing and discounting of retail goods is a factor in competitiveness, as more than $90 \%$ of respondents in a survey once a day or at least once a month change their shopping location to choose the most advantageous offer.

9) It is important to continue the research about the consumer's perception of the price and the price discounts, as well as the changes of the perception in the context of a sustainable economy. 


\section{Bibliography}

1. Arhipova, I., Balina, S. (2006). Statistika ekonomikā un biznesā. Riga: Datorzinību centrs. pp. 98 -233.

2. Blattberg, R.C. Neslin, S.A. (1990). Sales Promotion: Concepts, Methods, and Strategies. New York:. Prenctice Hall. p 513.

3. Blut, M.,Teller, C.,Floh, A. (2018). Testing Retail Marketing-Mix Effects on Patronage: A Meta-Analysis. Journal of Retailing, Volume 94, Issue 2, pp. 113-135.

4. Blythe, J. (2006). Essential of Marketing Communications. UK: Ashford Colour Press Ltd. p.332.

5. Carlson, J.R., Kukar-Kinney, M. (2018). Investigating Discounting of Discounts in an online context: The mediating effect of discount credibility and moderating effect of online daily deal promotions. Journal of Retailing and Consumer Services, Volume 41, pp. 153-160

6. Chernev, A. (2012). Strategic Marketing management. USA: Cerebellum Press. P.246.

7. Cummins, J. (2010). Sales Promotion; How to Create and Implement Campaigns that Really Work. London: Kogan Page, p. 280.

8. Davis, J. (2017) Measuring Marketing : The 100+ Essential Metrics Every Marketer Needs, Third Edition. Berlin : De|G Press., p. 376.

9. Goodluck, C. Wineaster. A,( 2016). International Marketing : Theory and Practice From Developing Countries. Newcastle: Cambridge Scholars Publishing, p.235.

10. Graciola, A. P., De Toni, D. (2018). Does price sensitivity and price level influence store price Image and repurchase intention in retail markets? Journal of Retailing and Consumer Services, Volume 44,pp. 201-213.

11. Jadidi, O., Jaber, M. Y., Zolfaghari, S. (2017). Joint pricing and inventory problem with price dependent stochastic demand and price discounts. Computers \& Industrial Engineering, Volume 114, pp.45-53

12. Kotler, P., Armstrong, G., Wong, V., Saunders, J. (2011). Principles of Marketing. $5^{\text {th }}$ Europe an Edition, London. Pentice Hall. p. 1056

13. Kotler, P., Keller, K.L. (2009). Marketing Managment. Pearson. p. 832.

14. Kristapsone, S., Kamerāde, D.u.c. (2011). Ievads pētniecībā: stratēǵijas, dizaini, metode. RaKa, Rīga, 284 Ipp.

15. Latvijas mazumtirdzniecības apgrozījums 2013.-2017.g. tūkst.eiro. Iegūts 13.02.2019. No http://www.csb.gov.Iv/lv/stats_table_metadata/68/ TARGET=_blank $>$ Metadati $</ A>$

16. Liu, H-H., Chiu, Y-Y. (2015). Sales framing, mental accounting, and discount assignments. Asia Pacific Management Review. Volume 20, Issue 4, December, pp.201-209.

17. Mao, W.(2016). Sometimes "Fee” Is Better Than „Free”: Token Promotional Pricing and Consumer Reactions to Price Promotion Offering Product Upgrades. Journal of Retailing, Volume 92, Issue 2, pp. 173-184.

18. Mazumtirdzniecības nozares tendences 2017. gadā un 2018. gada sākumā.(Maxima mazumtirdzniecības KOMPASS) (2018). Retrieved: https://www.maxima.Iv/fileman/Uploads/2018/Maxima-13-03-2018-RGB.pdf. Access: 04.01.2019

19. Miettinen,T., Stenbacka, R. (2018). Strategic short-termism: Implications for the management and acquisition of customer relationships. Journal of Economic Behavior \& Organization. Volume 153, pp. 200222.

20. Mohamed R. (2010). The $1 \%$ windfall. How successful companies use price to profit and grow. New York: HarperCollins Publisher, p. 224

21. Norton, p. (2005). The Manager's Guide to Competitive Marketing Strategies. London : Thorogood, p.414.

22. Ruskin-Brown, I. (2008). Practical pricing for results. London: Thorogood Publishing Ltd, p. 371.

23.Shirai, M. (2017). Effects of price reframing tactics on consumer perceptions. Journal of Retailing and Consumer Services. Volume 34, pp. 82-87.

24.Stiving, M. (2011). Impact Pricing: Your Blueprint for Driving Profits. Wisconsin: Entrepreneur Press, p.194.

25. Xu, X., Chen, R., Zhang, J.(2019) Effectiveness of trade-ins and price discounts: A moderating role of substitutability. Journal of Economic Psychology. Volume 70, Pages 80-89. 